\title{
Development of High Power Lasers for Materials Interactions
}

\author{
L. A. Hackel
}

This article was submitted to Conference on Lasers and Electro Optics/European Quantum Electronics Conference, Munich, Germany, June 23-27, 2003

\section{April 11, 2003}

U.S. Department of Energy

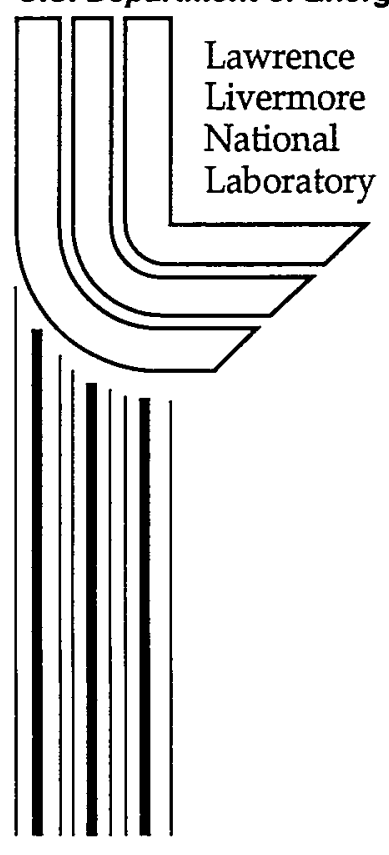




\section{DISCLAIMER}

This document was prepared as an account of work sponsored by an agency of the United States Government. Neither the United States Government nor the University of California nor any of their employees, makes any warranty, express or implied, or assumes any legal liability or responsibility for the accuracy, completeness, or usefulness of any information, apparatus, product, or process disclosed, or represents that its use would not infringe privately owned rights. Reference herein to any specific commercial product, process, or service by trade name, trademark, manufacturer, or otherwise, does not necessarily constitute or imply its endorsement, recommendation, or favoring by the United States Government or the University of California. The views and opinions of authors expressed herein do not necessarily state or reflect those of the United States Government or the University of California, and shall not be used for advertising or product endorsement purposes.

This is a preprint of a paper intended for publication in a journal or proceedings. Since changes may be made before publication, this preprint is made available with the understanding that it will not be cited or reproduced without the permission of the author.

This work was performed under the auspices of the United States Department of Energy by the University of California, Lawrence Livermore National Laboratory under contract No. W-7405-Eng-48.

This report has been reproduced directly from the best available copy.

Available electronically at http://www.doc.gov/bridge

Available for a processing fee to U.S. Department of Energy

And its contractors in paper from

U.S. Department of Energy

Office of Scientific and Technical Information

P.O. Box 62

Oak Ridge, TN 37831-0062

Telephone: (865) 576-8401

Facsimile: (865) 576-5728

E-mail: reports@adonis.osti.gov

Available for the sale to the public from

U.S. Department of Commerce

National Technical Information Service

5285 Port Royal Road

Springfield, VA 22161

Telephone: (800) 553-6847

Facsimile: (703) 605-6900

E-mail: orders@ntis.fedworld.gov

Online ordering: http://www.ntis.gov/ordering.htm

OR

Lawrence Livermore National Laboratory

Technical Information Department's Digital Library

http://www.llnl.gov/tid/Library.html 


\title{
Development of High Power Lasers for Materials Interactions
}

\author{
Lloyd A. Hackel \\ Program leader for Laser Science and Technology \\ Lawrence Livermore National Laboratory \\ Livermore CA 94550
}

\section{Paper}

The Lawrence Livermore National Laboratory (LLNL) has a long history of developing high power lasers for use in basic science and applications. The Laser Science and Technology Program (LS\&T) at LLNL supports advanced lasers and optics development both for the National Ignition Facility (NIF) as well as for high power lasers and optics technology for a broader range of government, military and industrial applications.

The NIF laser is currently under construction with the first of the 192 beamlines being activated. When finished NIF will have an output energy of $2 \mathrm{MJ}$ at $351 \mathrm{~nm}$. This system will be used for studies of high energy density physics, equation of state and inertial confinement fusion.

It is now generally acknowledged that the future of laser missile defense lies with solid state lasers. The leading laser technology for theater missile defense is under development within the Laser Science and Technology Program (LS\&T) and funded by the US Army SMDC. This high average power technology is based on a solid state laser operated in a heat capacity mode. In the concept the heat producing lasing cycle is separated in time from the cooling cycle thus reducing thermal gradients and allowing significantly greater average output power. Under the current program, an LLNL developed laser has achieved a record setting $13 \mathrm{~kW}$ of average power in 20 second duration bursts. We have also performed target lethality experiments showing a previously unrecognized advantage of a pulsed laser format. The LLNL work is now focused on achieving improved output beam quality and in developing a $100 \mathrm{~kW}$ output with diode pumping of a large aperture crystal gain medium on a compact mobile platform.

The Short Pulse Laser Group of LS\&T has been developing high power short pulse laser systems for a number of applications. Of great importance is petawatt $\left(10^{12} \mathrm{Watt}\right)$ and greater power output to support experiments on the NIF. We are developing a system of $5 \mathrm{~kJ}$ class output and 5 to $10 \mathrm{ps}$ pulse duration for generating intense radiation for radiography, particle beam generation and eventually for a new class of fusion experiments call fast ignition. We have also built a record setting 50 watts of average output from a picosecond class laser and are using this technology for materials processing such as fine hole drilling and safe cutting of munitions.

The laser science and technology program has developed and deployed a laser guide star on the Lick telescope on Mt. Hamilton and most recently on the Keck telescope in 
Hawaii. Our current development work in this area is focused on developing a much more compact all solid state diode pumped laser fiber system.

Finally in a program originally initiated by DARPA we have developed a phase conjugated Nd:glass laser system with record setting performance and successfully deployed it for Navy and Air Force satellite imaging applications and have more recently successfully transferred it to industry for use in an emerging technology called laser peening. This laser technology is capable of $25 \mathrm{~J}$ to $100 \mathrm{~J}$ per pulse, $10 \mathrm{~ns}$ to $1000 \mathrm{~ns}$ pulse duration, $5 \mathrm{~Hz}$ laser. The technology has been industrially deployed and is proving to be highly effective in generating high intensity shocks that induce compressive residual stress into metal components. The compressive stress retards fatigue and stress corrosion cracking and is proving to extend the lifetime of high value components by factors of ten. This processing adds lifetime, enhances safety and can improve performance of aircraft systems. Laser peening is now being evaluated to reduce the weight of aircraft and may play a major role in the future combat system and its air transport by enabling lighter craft, longer range and greater payload. The laser peening technology is also being moved forward in NRC license application as the means to eliminate stress corrosion cracking for Yucca Mountain nuclear waste disposal canisters as well as a broad range of other applications. 